\title{
Cross sectional study of knowledge and attitude of dental practitioners about the use of rubber dam in endodontic procedures in urban area of Andhra Pradesh
}

\author{
Krishnaveni Marella \\ Post Graduate, Dept.of Conservative Dentistry and Endodontics, G Pulla Reddy Dental College and Hospital, Kurnool, Andhra \\ Pradesh, India
}

*Corresponding Author:

Email: krishnavenimds@gmail.com

\begin{abstract}
Introduction: One of the prerequisite for the numerous endodontic and operative procedures is use of rubber dam which is an absolute necessity.

Objectives: To assess the knowledge and attitude of dental practitioners about the rubber dam use during endodontic treatment of anterior and posterior teeth.

Materials and Method: A hospital based cross sectional study was carried out in the urban area of Kurnool District of Andhra Pradesh. 90 clinics which were having conservative and endodontics speciality were selected for the study. A prevalidated close ended questionnaire was used. Details about the basic sociodemographic characteristics, information with regard to rubber dam use during procedures, attitude of dentists towards its use and the reasons for whether non use of rubber dam was recorded.

Results: A total of 90 questionnaires were mailed to dental practitioners in the urban locality. With respect to response to the use of rubber dam during endodontic procedures $13.72 \%$ of males and $12.82 \%$ of females responded that they were always using the rubber dam,5.88\% of males and $5.19 \%$ of females used rubber dam very oftenly.17.64\% and $2.56 \%$ of male and female participants used it occasionally. With regard to rubber dam use for the endodontic treatment procedures of the root canal of posterior teeth $15.68 \%$ of males and $12.82 \%$ of females responded that they were always using the rubber dam,5.88\% of males and $5.19 \%$ of females used rubber dam very oftenly. $17.64 \%$ and $2.56 \%$ of male and female participants used it occasionally.

Conclusion: Hence it can be stated that for creating awareness among dental practitioners about the importance of rubber dam in endodontic procedure by continuing dental educations is the need of the hour to improve the quality of dental care.
\end{abstract}

Keywords: Rubber Dam, Endodontics, Knowledge, Attitude.

\section{Introduction}

One of the prerequisite for the numerous endodontic and operative procedures is use of rubber dam which is an absolute necessity. ${ }^{1,2}$ The tooth can be isolated from anatomical structures like tongue, cheeks and lips during endodontic procedures by the proper use of Rubber dam thereby aseptic field can be maintained during treatments such as filling, ${ }^{3}$ aspiration of materials, instruments, irrigants or solvents ${ }^{4}$ and drastic reduction of risk of transmission of infective organisms between patient and dentist, ${ }^{5}$ oral soft tissues and gingiva can be protected from contact with harmful materials like liquids such as phosphoric acid or sodium hypochlorite. ${ }^{6}$

It also aids in retracting the soft tissues during endodontic procedures. $^{7}$ Hence this study was conducted to assess the knowledge and attitude of dental practitioners about the rubber dam use during endodontic treatment of anterior and posterior teeth.

\section{Materials and Method}

A hospital based cross sectional study was carried out in the urban area of Kurnool District of Andhra Pradesh. 90 clinics which were having conservative and endodontics specialty were selected for the study. Approval from the Institutional Ethical Committee was taken for conducting the study. After explain about the purpose of the study to dental practitioners verbal informed consent was obtained. A prevalidated questionnaire designed by Shipra Shukla et $\mathrm{al}^{1}$ was used in our study. It was a close ended questionnaire containing details about the basic sociodemographic characteristics, information with regard to rubber dam use during procedures, attitude of dentists towards its use and the reasons for whether rubber dam is used or not. Data was collected by mailing the questionnaires to the practitioners. The collected data was compiled and analyzed by using SPSS software version 22. Statistical tests like student $t$ test and Chi square was applied for assessing the knowledge and attitude. $\mathrm{p}$ value $<0.05$ was considered statistically significant.

\section{Results}

A total of 90 questionnaires were mailed to dental practitioners in the urban locality. Most of the study participants belonged to 30-49 years age group.

With respect to response to the use of rubber dam during endodontic procedures $13.72 \%$ of males and $12.82 \%$ of females responded that they were always using the rubber dam,5.88\% of males and $5.19 \%$ of females used rubber dam very oftenly.17.64\% and $2.56 \%$ of male and female participants used it occasionally, $11.76 \%$ and $30.76 \%$ of male and female participants respectively responded that rarely they use rubber dam whereas the never use response was $43.13 \%$ and $43.58 \%$ among male and female 
practitioners respectively (Table 1).

With regard to rubber dam use for the endodontic treatment procedures of the root canal of posterior teeth $15.68 \%$ of males and $12.82 \%$ of females responded that they were always using the rubber dam,5.88\% of males and $5.19 \%$ of females used rubber dam very oftenly.17.64\% and $2.56 \%$ of male and female participants used it occasionally, $11.76 \%$ and $30.76 \%$ of male and female participants respectively responded that rarely they use rubber dam whereas the never use response was $43.13 \%$ and $43.58 \%$ among male and female practitioners respectively (Table 2 ).

\section{Discussion}

In our study it was found that rubber dam use by the dental care practitioners is extremely low. In endodontic procedures rubber dam usage has numerous benefits in controlling the infections and patient safety however probably due to reasons they prefer not using it while treating patients for endodontic problems. Because they prefer cotton rolls will do rather than rubber dam. Study by Ansbtawi $\mathrm{MF}^{8}$ (2013) among 524 DPBRN practitioners, $44 \%$ responded that they use rubber dam for all types of root canal treatment, $24 \%$ use it most of the time and $17 \%$ very occasionally whereas $15 \%$ of practitioners said that they never use rubber dam procedures. The study also reported use of cotton rolls and other modes of isolation. This may due to more time needed for its application although the process is easy and simple.

Another study by G S, Jena A et $\mathrm{al}^{9}$ (2014) reported that low prevalence of rubber dam use for root canal treatment .only $30 \%$ of the study participants were using rubber dam for root canal treatments and $23 \%$ responded that they were using it for all the root canal procedures . Survey by $\mathrm{HC}$ et $\mathrm{al}^{10}$ among dentists enrolled under in Taiwan's National Health Insurance system it was reported that the prevalence of rubber dam use was $16.5 \%$ which was similar to our study findings.

A study done among dentists in Nigeria by Udoye CI et $\mathrm{al}^{11}$ (2010) also reported the same as the prevalence of rubber dam usage was around $18 \%$ and $77 \%$ reported that they never use rubber dam. The reason was probably lack of awareness about the importance of rubber dam use in key endodontic procedures.

Table 1: Age and sex wise comparison of rubber dam use for anterior toot treatment

\begin{tabular}{|l|c|c|c|c|c|}
\hline $\begin{array}{c}\text { Rubber dam } \\
\text { usage in } \\
\text { anterior root } \\
\text { canal }\end{array}$ & \multicolumn{3}{|c|}{ Age in years (\%) } & \multicolumn{2}{c|}{ Gender (\%) } \\
\hline treatment & $<30$ & $31-50$ & $>50$ & Males & Females \\
\hline Never used & $7(41.17)$ & $28(41.79)$ & $2(33.33)$ & $22(43.13)$ & $17(43.58)$ \\
\hline Rarely used & $4(23.59)$ & $10(14.92)$ & $2(33.33)$ & $6(11.76)$ & $12(30.76)$ \\
\hline Occasionally & $4(23.59)$ & $11(16.41)$ & $0(0)$ & $9(17.64)$ & $1(2.56)$ \\
\hline Often used & $0(0)$ & $5(7.46)$ & $1(16.67)$ & $3(5.88)$ & $2(5.19)$ \\
\hline Most of the time & $2(11.76)$ & $34(4.47)$ & $1(16.67)$ & $4(7.84)$ & $3(7.69)$ \\
\hline Always & $2(11.76)$ & $10(14.92)$ & $0(0)$ & $7(13.72)$ & $5(12.82)$ \\
\hline Total & $17(18.9)$ & $67(74.44)$ & $6(6.66)$ & $51(56.66)$ & $39(43.34)$ \\
\hline $\mathrm{P}=0.13$ & \multicolumn{7}{|l|}{} & & \\
\hline
\end{tabular}

Table 2: Age and sex wise comparison of rubber dam use for posterior toot treatment

\begin{tabular}{|l|c|c|c|c|c|}
\hline \multirow{2}{*}{$\begin{array}{c}\text { Rubber dam usage } \\
\text { in posterior root } \\
\text { canal treatment }\end{array}$} & \multicolumn{3}{|c|}{ Age in years (\%) } & \multicolumn{2}{c|}{ Gender (\%) } \\
\cline { 2 - 6 } & $<30$ & $31-50$ & $>50$ & Males & Females \\
\hline Never used & $7(41.17)$ & $28(41.79)$ & $2(33.33)$ & $22(43.13)$ & $17(43.58)$ \\
\hline Rarely used & $4(23.59)$ & $10(14.92)$ & $2(33.33)$ & $6(11.76)$ & $12(30.76)$ \\
\hline Occasionally & $4(23.59)$ & $11(16.41)$ & $0(0)$ & $9(17.64)$ & $1(2.56)$ \\
\hline Often used & $0(0)$ & $5(7.46)$ & $1(16.67)$ & $3(5.88)$ & $2(5.19)$ \\
\hline Most of the time & $2(11.76)$ & $34(4.47)$ & $1(16.67)$ & $3(5.88)$ & $3(7.69)$ \\
\hline Always & $2(11.76)$ & $10(14.92)$ & $0(0)$ & $8(15.68)$ & $5(12.82)$ \\
\hline Total & $17(18.9)$ & $67(74.44)$ & $6(6.66)$ & $51(56.66)$ & $39(43.34)$ \\
\hline $\mathrm{P}=0.12$ & \multicolumn{5}{|l}{} \\
\hline
\end{tabular}




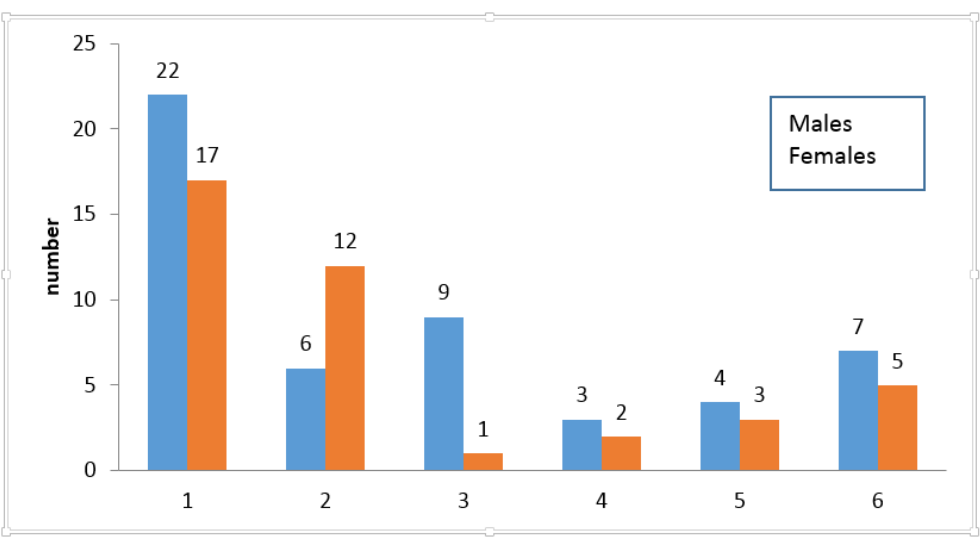

$1=$ never, $2=$ rarely, $3=$ occasionaly, $4=$ ofetn, $5=$ mostly, $6=$ always

Fig. 1: Gender wise comparison of rubber dam use in anterior tooth treatment

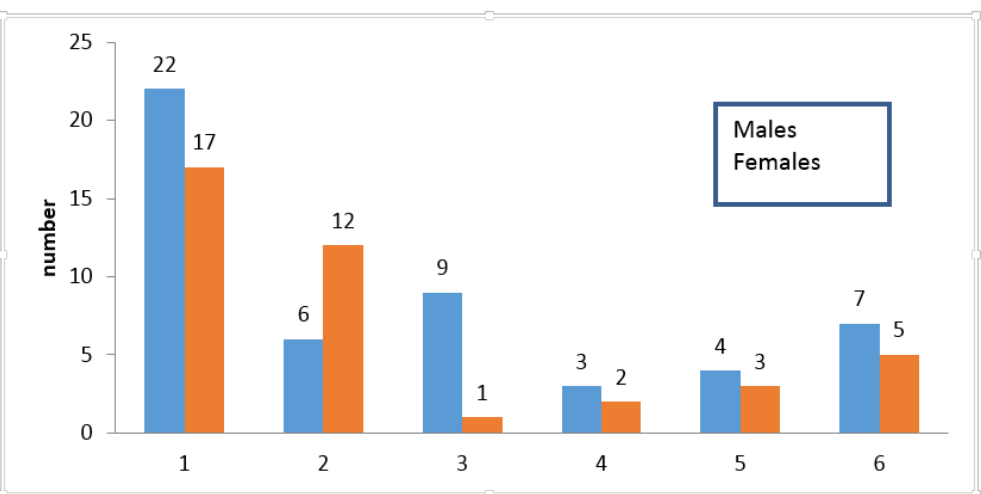

$1=$ never, $2=$ rare, $3=$ occasional, $4=$ often, $5=$ mostly, $6=$ always

Fig. 2: Gender wise comparison of rubber dam use in treatment posterior tooth

\section{Conclusion}

From our study it can be concluded that most of the dental practitioners were never using the rubber dam and it was in case of posterior teeth treatment compared to anterior one. Hence it can be stated that for creating awareness among dental practitioners about the importance of rubber dam in endodontic procedure by continuing dental educations is the need of the hour to improve the quality of dental care.

\section{References}

1. Shipra shukla et al. The assessment of attitude and knowledge of local dental practitioners regarding use of rubber dam in endodontic treatment of anterior and posterior teeth. Ind J Rest Dent 2016;5(3):29-32.

2. Barnum SC (1877) History of the discovery of the dam. Can J Dent Sci 4, 88-9.

3. Cochran MA, Miller CH, Sheldrake MA (1989); The efficacy of the rubber dam as a barrier to the spread of microorganisms during dental treatment. J Am Dent Asso 119,141-4.

4. Cohen S, Schwartz SF (1987) Endodontic complications and the law. J Endod 13, 191-7.

5. Forrest W, Perez RS (1989) The rubber dam as a surgical drape: protection against aids and hepatitis. J Acad Gen Dent 37, 236-7.

6. Carrotte PV (2000) Current practice in endodontics: 4. A review of techniques for canal preparation. Dent Update 27, 488-93.
7. Reid JS, Callis PD, Patterson CJW (1991) Rubber Dam in Clinical Practice. London: Quintessence Publishing Co.

8. Anabtawi MF, Gilbert GH, Bauer MR, et al. Rubber dam use during root canal treatment: findings from The Dental Practice-Based Research Network. J Am Dent Asso 2013;144(2):179-86.

9. G S, Jena A, Maity AB, Panda PK. Prevalence of Rubber Dam Usage during Endodontic Procedure: A Questionnaire Survey. J Clin Diagn Res 2014;8(6):ZC01ZC03. doi:10.7860/JCDR/2014/9011.4425.

10. Lin HC, Pai SF, Hsu YY, Chen CS, Kuo ML, Yang SF; Use of rubber dams during root canal treatment in Taiwan. J Formos Med Assoc 2011 Jun;110(6):397-400. doi: 1016/S0929-6646(11)60058-2.

11. Udoye CI, Jafarzadeh $\mathrm{H}$. Rubber dam use among a subpopulation of Nigerian dentists. J Oral Sci 2010 Jun;52(2):245-9. 